\title{
Studies on the Monogenea of Plymouth. Gastrocotyle trachuri v. Ben. and Hesse, 1863.
}

By

\author{
By E. Idris Jones, B.Sc. (Lond.)
}

With 4 Figures in the Text.

In August, 1932, six specimens of this species were found on the gills of Trachurus [Caranx] trachurus taken at Plymouth. This is the first record of its occurrence in British waters.

The genus and species were first defined by van Beneden and Hesse (1864), their description being from young specimens, and incomplete in numerous details. No account of the internal organs is given, the genital opening is not described and the number of crotchets or hooks at the posterior end of the body is said to be four. This undoubtedly arises from the fact that their specimens were immature, being $1.5 \mathrm{~mm}$. in length, whereas the specimens found at Plymouth are circa $4 \cdot 7 \mathrm{~mm}$.

Of subsequent authors Taschenberg (1879, a and b) refers to Gastrocotyle, but depends on van Beneden and Hesse's description and adds no new details. J. T. Cunningham (1887) refers to Gastrocotyle in a discussion on the systematic position of Stichocotyle, but again contributes no new details. Monticelli (1888) discusses its systematic position, depending on van Beneden and Hesse's description ; von Linstow (1889) mentions Gastrocotyle in his Compendium, but the first record of its occurrence after van Beneden and Hesse's discovery comes from Paroni and Perugia $(1890, a)$ who found it on the gills of Trachurus trachurus at Genoa and later in the same year $(1890, b)$ published a description of the species. This account is a big advance on that of van Beneden and Hesse, but is still incomplete. The reproductive organs are said to be similar to those of Microcotyle, but no description is given. Six crotchets are described at the posterior end of the body and the cotylophore bears 35 suckers. The measurements of their specimens are $3 \mathrm{~mm} . \times 1 \mathrm{~mm}$. Unfortunately the armature of the suckers is not figured. Braun (1893), Pratt (1900), Monticelli (1903), Nicoll (1915), and Brown (1929) all make references to the species, but no new data or records are added.

The specimens here described were found during an investigation at Plymouth on the trematodes of fishes. During this investigation it was repeatedly noticed that when copepods were present on the gills 


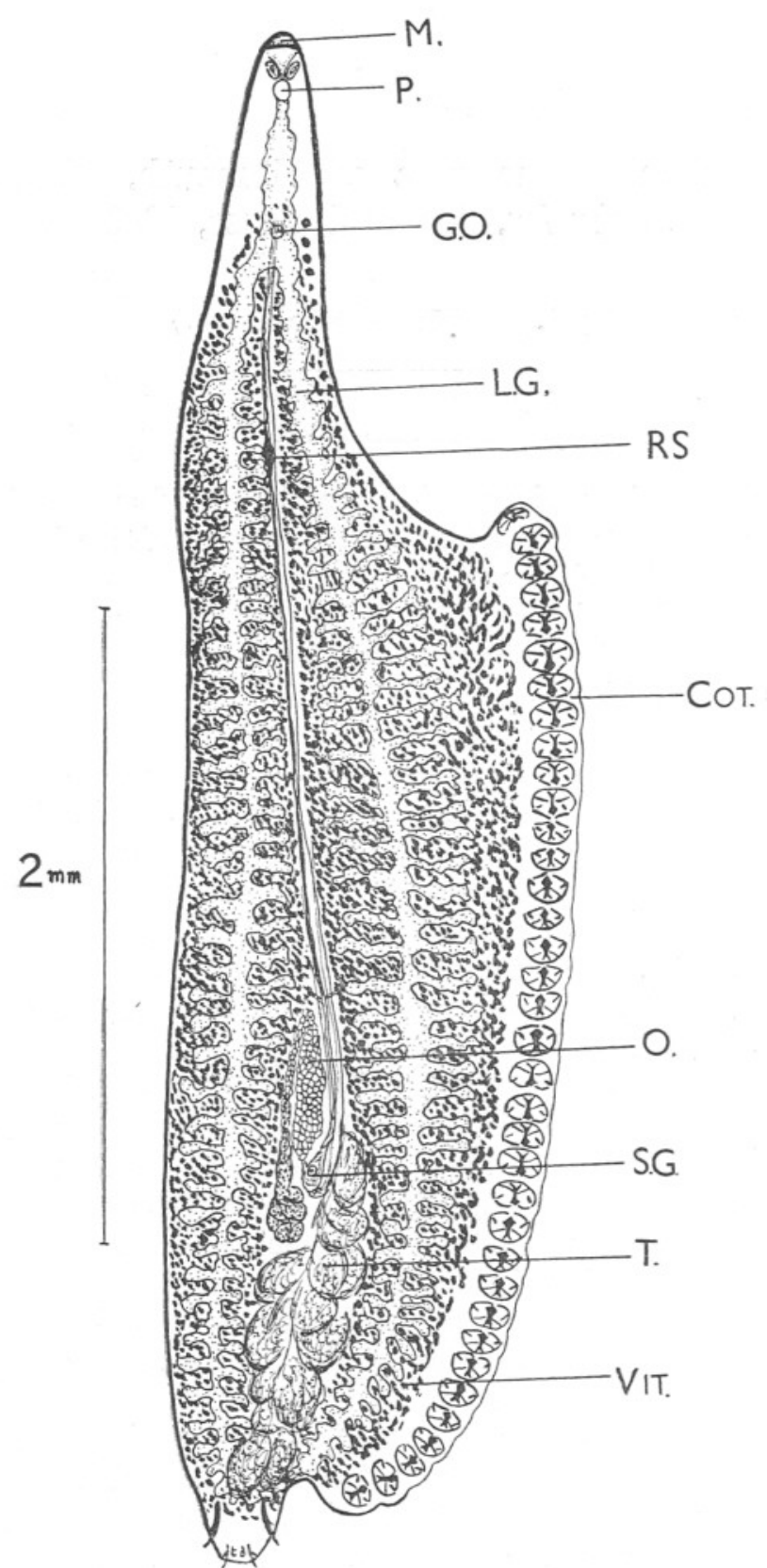

FIG. 1.-Gastrocotyle trachuri. Whole animal. Ventral view. COT. $=$ cotylophore ; G.O. $=$ genital opening ; L.G. $=$ limb of gut $; \mathrm{M} .=$ mouth $; \mathrm{O}=$ ovary; $\mathrm{P} .=$ pharynx $; \mathrm{R} . \mathrm{S} .=$ receptaculum seminis; S.G. $=$ shell-gland ; T. $=$ testis ; VIT. $=$ vitellaria. 
trematodes were seldom found and vice versa - a fact also noticed by W. H. Leigh-Sharpe (1933).

Gastrocotyle trachuri (Fig. 1) is an elongated worm $4.7 \mathrm{~mm}$. long, narrow in its anterior third but considerably broader $(1.2 \mathrm{~mm}$.) in its posterior two-thirds along the left side of which is borne the cotylophore. The cotylophore bears one series of 32-40 suckers, each sucker measuring $0.08 \mathrm{~mm}$. in diameter. Van Beneden and Hesse (1864) give the number of suckers as 31-38, and Paroni and Perugia (1890) as about 35. The
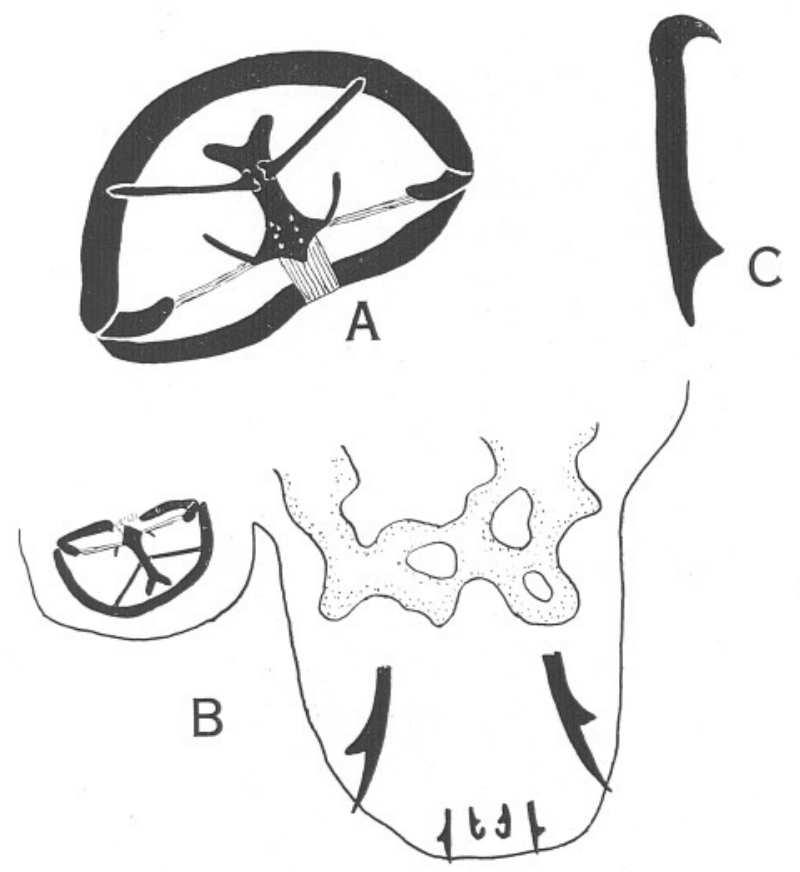

FIG. 2.-A. Armature of sucker; B. Posterior end of body ; C. Crotchet from genital opening.

armature of the suckers (Fig. 2, A) is very different from that described by van Beneden and Hesse. At the extreme posterior end of the body are 6 uncini, the lateral pair being large and stout and the two medial pairs small (Fig. 2, B).

The Alimentary System. The mouth is terminal at the anterior end and leads into a buccal cavity in which are situated two lateral oval suckers measuring $23 \mu \times 15 \mu$. From the buccal cavity emerges the pharynx, measuring $46 \mu \times 30 \mu$, which leads into the œsophagus. The œsophagus is $0.2 \mathrm{~mm}$. in length and has pouches in its walls but no actual diverticula. The gut extends down on either side of the body and has numerous 
diverticula and in the posterior end of the body the limbs of the gut anastomose (Figs. 1 and 2, B).

The Reproductive System (Fig. 3). The testes and ovary are situated in the posterior third of the body in the mid-line. The testes are situated more posteriorly and consist of closely apposed lobules. The vasa

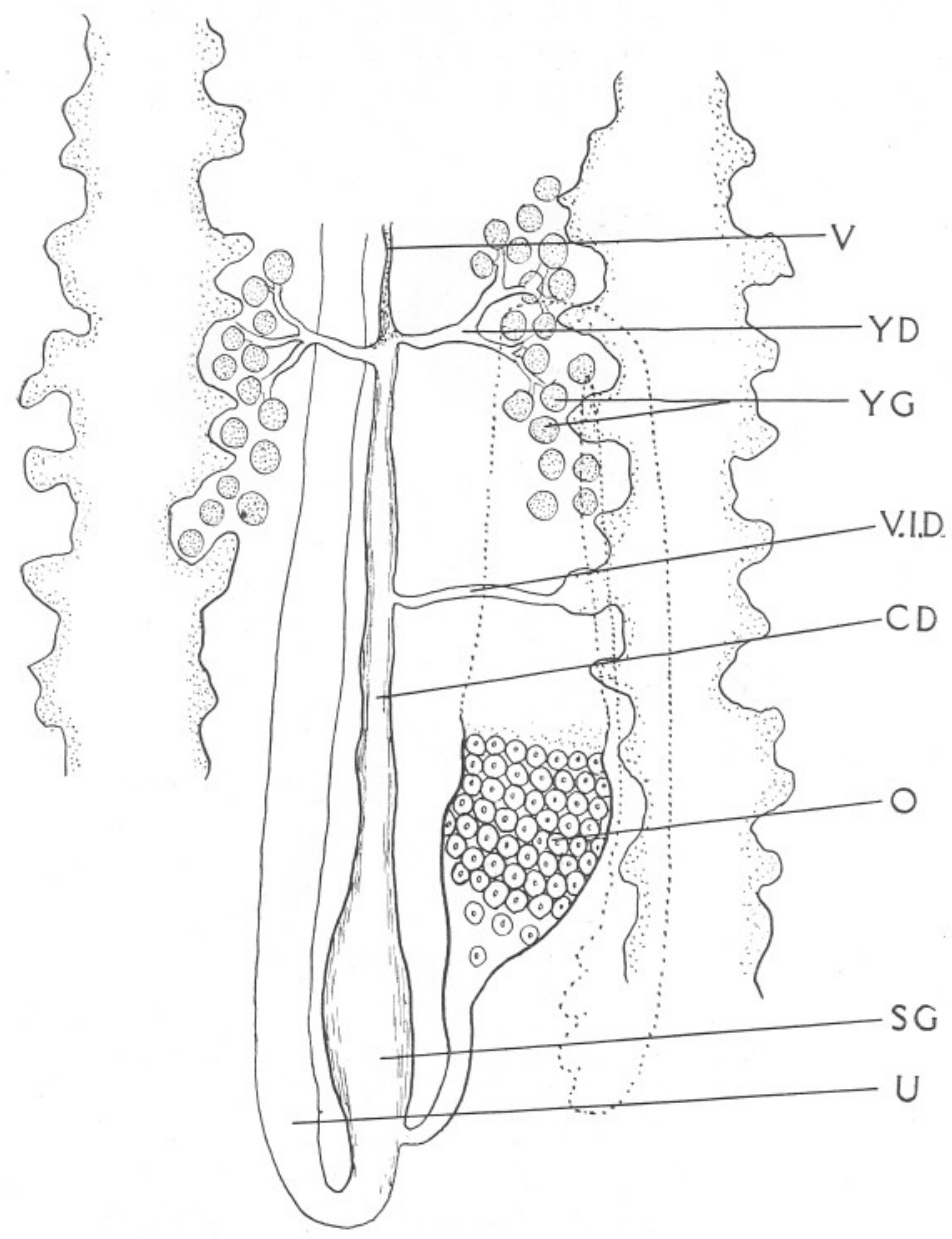

Fig. 3.-Shell-gland and associated structures. C.D.= connecting duct ; O.=ovary (partially in outline) ; S.G.=shell-gland; U.=uterus; V.= vagina ; V.I.D. = vitello-intestinal duct ; Y.D. =yolk-duct ; Y.G.= yolk-glands.

efferentia unite to form a fine vas deferens which passes in close apposition to the uterus up to the genital atrium into which it opens. The ovary is a $\mathrm{n}$-shaped organ containing ripe ova in one extremity, from which emerges a short oviduct which leads into the shell-gland. From the shell-gland 
emerges the uterus which is a non-convoluted wide thin-walled tube leading up to the genital atrium into the base of which it opens (Fig. 4).

The genital atrium (Fig. 4) is a muscular sac $23 \mu$ in diameter, and at its apex is the genital opening which is situated in the mid-line ventrally, a short distance from the anterior end of the body. The opening is guarded by 12 crotchets arranged in a circle. Each crotchet (Fig. 2, C) has a bifurcate base and a hooked extremity, not a simple base and a flattened diamond-shaped extremity as described by Paroni and Perugia $(1890, \mathrm{~b})$.

The vagina opens in the mid-line on the dorsal surface a short distance

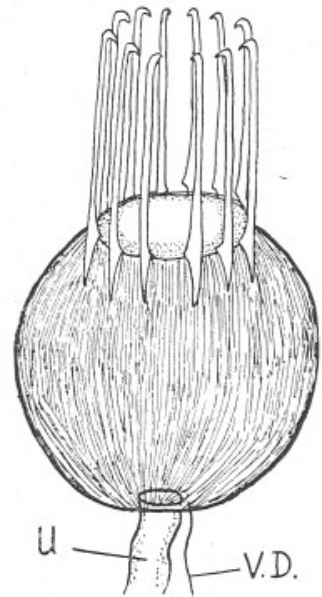

Fig. 4.-Genital atrium and opening. U.=uterus ; V.D.=vas deferens.

behind the genital opening. It leads into a receptaculum seminis from which a duct emerges which proceeds downwards between the uterus and vas deferens and at the level of the upper border of the ovary receives the vitelline ducts on each side and then passes down into the shell-gland (Fig. 3), giving off the vitello-intestinal duct on the left.

The vitellaria are scattered diffuse lobules lying between the diverticula of the gut and a few lie anterior to the genital opening. None pass into the cotylophore.

The eggs are described by van Beneden and Hesse, and Paroni and Perugia as possessing two short filaments. No eggs were found in these specimens, so this fact cannot be confirmed.

I am indebted to my friend and former teacher, Mr. W. H. LeighSharpe, for his help in finding these specimens. 


\section{REFERENCES.}

van Beneden, P. J., and Hesse, E. (1864). Recherches sur les Bdellodes et les Trematodes Marines. Mem. Acad. Roy. Soc. Belgique, Vol. 34, pp. 117-118.

Braun, M. (1893). In Bronn's Klassen und Ordnung d. Thier-Reichs. Leipzig. Vol. 5, No. 4, p. 890.

Brown, E. M. (1929). On a new species of monogenetic trematode. Proc. Zool. Soc., London, Part I, 1929, pp. 76-83.

Cunningham, J. T. (1887). On Stichocotyle nephropis. Trans. Roy. Soc., Edin., Vol. 32, pp. 273-280.

Leigh-Sharpe, W. H. (1933). On Argulus rothschildi. Parasitology, Vol. 24, No. 1, pp. 252-257.

Linstow, O. von (1889). Compendium der Helminthologie. Nachtrag, p. 77.

Monticelli, F. S. (1888). Saggio di una morfologia de $\mathrm{i}$ trematodi. Thesis, Naples, pp. 3-130.

Nicold, W. (1915). A list of the trematode parasites of British marine fishes. Parasitology, Vol. 7, No. 4, pp. 339-378.

Paroni, C., and Perugia, A. (1890, a). Trematodi parassiti delle branchie de i pesci italiana. Atti. Soc. Ligusta di sc. e-geogr., Genova, Vol. 1, No. 1, pp. 59-70.

- $(1890$, b). On Gastrocotyle. Atti. Soc. Ligusta, Vol. 1, No. 3, pp. 225242.

Pratt, H. S. (1900). Synopsis of Monogenea. American Naturalist, Vol. 34, 'pp. 645-662.

Taschenberg, E. O. (1879, a). Weitere Beiträge zur Kentniss ectoparasitischer mariner Trematoden. Festschr. z. Feier d. 100 jähr Besteh. d. Naturf. Gesellsch. in Halle, pp. 25-76.

— (1879, b). Zur systematik der monogenetischen Trematoden. Zeitschr. f. ges. Naturw., Berlin, Vol. 52, pp. 232-265. 